\section{Shining a light on suffering}

\author{
The aid worker Vincent Hoedt was threatened \\ with three years in a Sudanese jail. He tells Tony \\ Sheldon that his experience was worth while
}

"Sudanese government tries to silence aid workers," the headline from Associated Press proclaimed at the end of May, while the $\mathrm{BBC}$ carried the message "Second Sudan aid worker arrested."

The articles told the world of the arrest by the Sudanese authorities of Vincent Hoedt, the Darfur coordinator for the Dutch section of Médecins Sans Frontières. He had been thrown into jail a day after the same authorities had seized Paul Foreman, the head of the section. Both men were charged with spying, destabilising society, and publishing false information.

Their real crime, however, had been to publish a report on the brutal rape of African women in Darfur by armed militia men.

The report described how between October 2004 and February 2005 doctors from the agency had treated almost 500 women who had been raped in Darfur, most of whom had had to flee their villages and were living in makeshift camps. Many of the victims had been raped when they had ventured outside the camps to collect wood, fetch water, or work in the fields. Some of the rapists had told the women that they were raping them to change the colour of their children and force them to have "Arab babies."

Now released and back in the Netherlands, Vincent Hoedt can reflect in tranquillity on his 24 hour ordeal in prison, when his future looked uncertain and he thought he might face a three year jail sentence. He considers that it was worth while.

He points out that the Sudanese government could hardly claim that his organisation's report came "as a bolt from the blue." Last year evidence of mass rapes was already amassing as he began his latest posting to Sudan. Medical aid meetings with the Sudanese government included discussions on "gender based violence." The Sudanese government's own report referred to the problem.

The report nevertheless caused an outcry that discomfited the Sudanese authorities.

Hoedt described how the report was compiled. "You don't see the rape, but in the middle of nowhere you are confronted by people-who don't easily talk to men-who tell you, 'These women were raped.' We try to bring them to our clinics, recommend treatment, ask if they know of more cases."

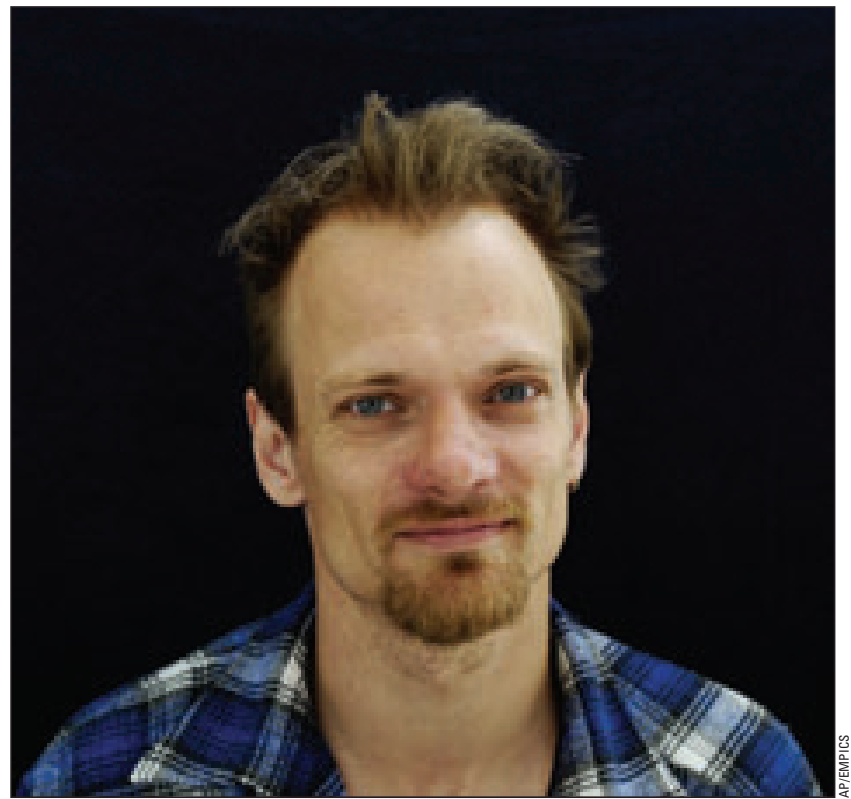

Vincent Hoedt says the Sudanese government could hardly claim that his organisation's report on rape came "as a bolt from the blue"

The report highlights the "horrific... daily reality" for the hundreds of thousands of displaced people and how rape of women, children, and men is a "constant factor." It shows that the rapes, sometimes gang rapes, are typically by armed men and often involve beating with sticks and abduction.

Hoedt explained that a picture was emerging of an abnormal "exploding" society in which rape, even more than displacement and malnutrition, represented "manmade human suffering."

His case illustrates clearly how aid workers often have to walk a dangerous tightrope. Host countries often claim that unusual. Throughout 20 years of good relations with the Sudanese government there had always been tension. "Some people tell us: you are here to provide services, we don't expect foreigners then to voice these things so openly.

"But we can never just provide services and not talk about it. Humanitarian action is more: it is about taking a sincere interest in your fellow human beings. the role of aid workers is simply to provide food and medica assistance, whereas aid workers often see themselves as advocates or champions of the people they help.

Médecins Sans Frontières decided to risk the political repercussions and speak out.

For Hoedt this was not

after three weeks all charges were dropped (BMJ 2005;330: 1464).

Hoedt is now phlegmatic about his "day in a dark prison." He says he was treated well and told it had been a mistake. He was worried and uncertain, especially about what information his family in Rotterdam were getting, but "it was not his worst experience" in 10 years with the charity.

"I don't want to be a martyr. I am not saying they can lock me away for ever, but I think it was worth it."

Although it wasn't a deliberate media campaign, he feels that the report and the coverage it received through the consequent arrests inadvertently "kept Darfur on the agenda."

"There is another reason why these stories should be told: to make political leaders know there is a problem. Then perhaps they will find a political solution."

He also hopes the attention will mean that international donors will be more motivated to continue their support. His organisation is keen to encourage the United Nations World Food Programme to maintain its commitment to feed two million people in Darfur. Without this, argues Hoedt, "malnutrition will shoot through the roof."

He passionately refutes criticism that the emergency medical aid from Médecins Sans Frontières and other agencies could inadvertently perpetuate problems, for example by delaying the development of local health services.

"What do we perpetuate by feeding malnourished kids, treating victims of rape, holding consultations for chest infections and diarrhoea? Do we perpetuate war by treating combatants for bullet wounds, even when these are found among women and children."

"I believe a lot in development. I studied tropical agriculture before joining MSF [Médecins Sans Frontières], but I do not believe that people who live in the stress of a cruel war like Darfur or the Congo have anything left to spare for development. If [some people's] village is going to be burned down you can't expect them to run their own feeding centres." Tony Sheldon Utrecht

The Crushing Burden of Rape: Sexual Violence in Darfur is available at www.artsenzondergrenzen.nl 